\title{
Behaviour analysis of the loggerhead sea turtle Caretta caretta from direct in-water observation
}

\author{
Gail Schofield ${ }^{1,4,}$, Kostas A. Katselidis ${ }^{1,2}$, Panayotis Dimopoulos ${ }^{1}$, John D. Pantis ${ }^{3}$, \\ Graeme C. Hays ${ }^{4}$ \\ ${ }^{1}$ Department of Environmental \& Natural Resources Management, University of Ioannina, G. Seferi 2, 30100 Agrinio, Greece \\ ${ }^{2}$ National Marine Park of Zakynthos, 1 El. Venizelou Str., 29100 Zakynthos, Greece \\ ${ }^{3}$ Department of Ecology, School of Biology, UP Box 119, Aristotle University of Thessaloniki, 54006 Thessaloniki, Greece \\ ${ }^{4}$ Department of Biological Sciences, Institute of Environmental Sustainability, University of Wales Swansea, \\ Singleton Park, Swansea SA2 8PP, UK
}

\begin{abstract}
Direct observation of animal behaviour is essential for the effective conservation of endangered species in their natural habitat, understanding their function within ecosystems and validating inferences made using remote technology. The aim of this study was to document the daytime behavioural activity of loggerhead sea turtles Caretta caretta at a temperate breeding area through direct observations. Between April and July of 2003 to 2005, turtle behaviour on initial sighting was recorded during $287 \mathrm{~h}$ of observation, comprising 1534 sighting events of solitary $(\mathrm{n}=80$ male, $\mathrm{n}=$ 1335 female) and social ( $\mathrm{n}=65$ same sex, $\mathrm{n}=54$ mixed sex) activity. We grouped observed activities into 4 solitary and 2 social behaviours, which were divided into 14 sub-categories. Solitary behaviour included resting, swimming, foraging and cleaning. Social behaviour included antagonistic interactions and reproductive activity. Foraging, cleaning and female-female contests are not documented in published literature for loggerhead sea turtles at breeding areas. Our results suggest that during the breeding period (1) male behaviour was primarily social and active (2) female behaviour was primarily solitary and inactive.
\end{abstract}

KEY WORDS: Sea turtle $\cdot$ Behaviour $\cdot$ Solitary $\cdot$ Social $\cdot$ Activity $\cdot$ Interaction

\section{INTRODUCTION}

Direct observation of animals in their natural environment contributes important information about how species adapt to a particular environment. Information about behaviour and interactions at the level of individuals is key to understanding how an animal may impact the surrounding community as well as ecosystem function, organisation and response to disturbance (Piraino et al. 2002). Hence, studies of behaviour in the field are fundamental for the effective conservation of animals in their natural habitats (Mills et al. 2005).

Direct observations in the marine realm are often restricted due to sea depth and state, underwater visi- bility, natural light availability, physical danger and adequate access to the study animal (Hooker \& Baird 2001). Due to the difficulties of studying large marine vertebrates in their natural habitats, most studies of their behaviour have relied on inferences from animalborne devices. For example, in sea turtle research devices such as data-loggers, radio and satellite telemetry are used (Hopkins-Murphy et al. 2003, Hochscheid et al. 2005, Myers et al. 2006). While useful, these techniques cannot describe the full range of behavioural patterns of wild animals that direct firstperson observations can (Houghton et al. 2002). To date, there have been few quantitative observational studies of sea turtles (Booth \& Peters 1972, Whittow \& 
Balazs 1982, Dodd 1988, Losey et al. 1994, Frick et al. 2000); however, the development of animal-borne cameras has provided the opportunity to observe and confirm the underwater behaviour of these and other marine vertebrates (Davis et al. 1999, Heithaus et al. 2002, Reina et al. 2005, Hays et al. 2006).

Sea turtles are endangered worldwide, therefore a detailed understanding of their behaviour is a key factor to be considered when drawing up effective conservation management policies. This is particularly important in coastal areas where marine oriented tourism is focused on sea turtles (Meadows 2004). On Zakynthos island in Greece, high densities of reproductively active loggerhead sea turtles and turtlewatching enterprises co-exist in a very restricted area each summer. Currently turtle watching protocols and permitted observation zones are evolving under the guidance of the National Marine Park of Zakynthos. However, due to the lack of knowledge about sea turtle behaviour and habitat use in this and similar coastal reproductive areas, decisions are not currently scientifically based.

Laganas Bay, in the National Marine Park of Zakynthos, is an ideal location for investigating the behaviour of loggerhead sea turtles Caretta caretta at a temperate breeding area. Several hundred adult turtles are found at nearshore aggregations for about 4 mo following migration into the bay each spring (Margaritoulis 2005). In sea turtles, mating and first nesting occur up to 6 wk apart (Wood \& Wood 1980, Miller et al. 2003), with females storing sperm to fertilize several clutches laid during the season at intervals of around $14 \mathrm{~d}$ (Hays et al. 2002a).

The aim of this study was to gather information about the behaviour of male and female loggerhead sea turtles in the marine environment during the breeding period. In this paper we (1) document the solitary and social behaviour of loggerhead sea turtles, and (2) discuss how differences in the proportions of observed male and female behaviour may reflect gender-specific strategies.

\section{MATERIALS AND METHODS}

Laganas Bay is situated at the southeastern part of the Greek island of Zakynthos (37 $43^{\prime} \mathrm{N}, 20^{\circ} 52^{\prime} \mathrm{E}$ ) (Fig. 1). The bay is generally shallow, reaching a depth of about $50 \mathrm{~m}$, with sea surface temperatures of $15^{\circ} \mathrm{C}$ in March rising to $28^{\circ} \mathrm{C}$ in August (Comprehensive Ocean Atmosphere Data Sets (COADS) database, www.cdc.noaa.gov/ coads/). In-water surveys have been conducted annually since 2003 to collect information about loggerhead sea turtle marine ecology from April to July during the breeding season. The nesting season runs from approximately late-May to early September (Margaritoulis et al. 2003). Hence, our surveys spanned the time during which there was still some mating activity, but many females had started nesting.

Surveys were conducted in Laganas Bay along a $5.5 \mathrm{~km}$ stretch of nearshore water, extending $1 \mathrm{~km}$ into the sea to depths of up to $10 \mathrm{~m}$ (Fig. 1). Surveys were conducted over a total of $287 \mathrm{~h}$ on $104 \mathrm{~d}$ across $3 \mathrm{yr}$ (2003 to 2005). Surveys were primarily concentrated in the afternoons between 12:00 and 18:00 h, lasting an average of $3 \mathrm{~h}$ (minimum 1 , maximum $7 \mathrm{~h}$ ). Observers entered the water from a boat, a kayak or directly from the shore.

Boat surveys ( $405 \mathrm{~km}, 137 \mathrm{~h}$ ) were conducted by 2 to 3 observers in April and May of 2003 on a $4 \mathrm{~m}$ boat with an outboard engine. Sessions lasted an average of $5 \mathrm{~h}$ (minimum 4, maximum $7 \mathrm{~h}$ ) at a maximum boat speed of 4 knots $\mathrm{km}^{-1}$. Line transects across the entire survey area were performed during each survey session that ran parallel to shore at sea depths of 10,7 , 5 and $3 \mathrm{~m}$.

Kayak surveys (77 km, $33 \mathrm{~h})$ were conducted by 2 observers in May and June of 2004 on 2 sea-kayaks at

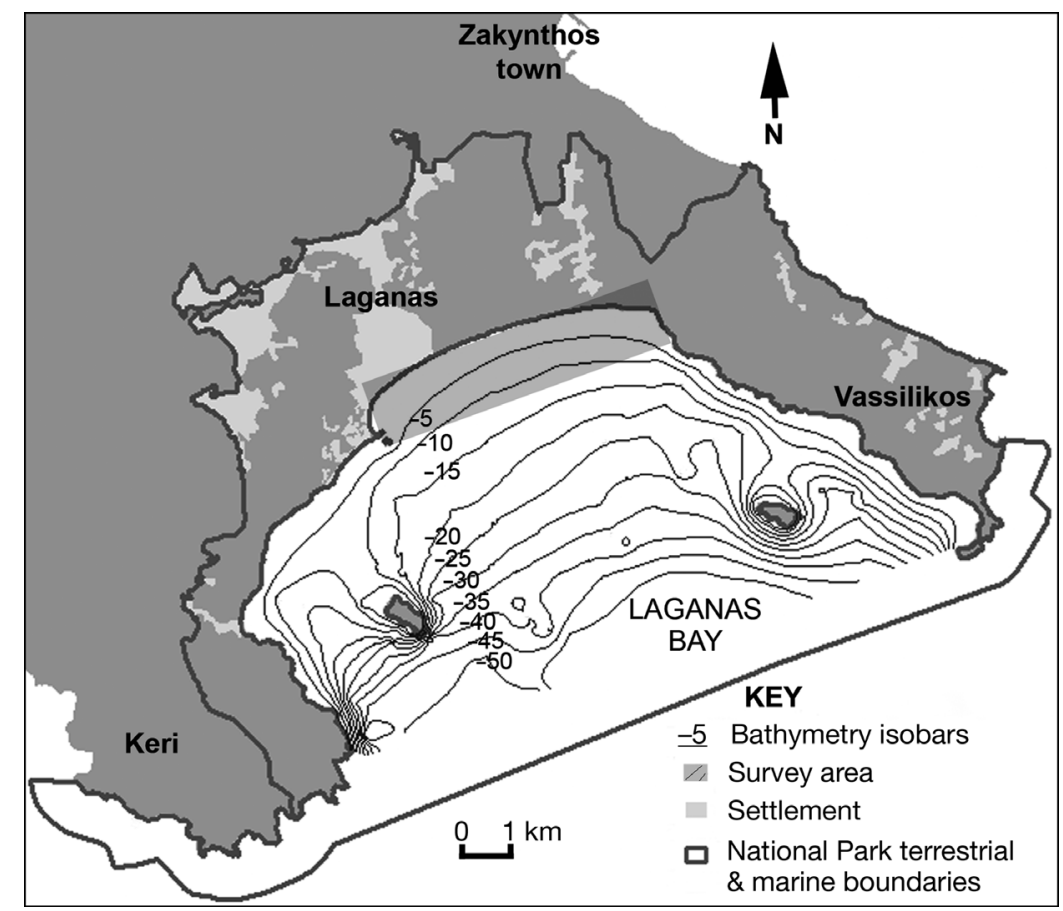

Fig. 1. Laganas Bay situated on the southern part of Zakynthos Island, showing the survey area 
randomly selected sites within the survey area. Sessions lasted an average of $2 \mathrm{~h}$ (minimum 1, maximum 3 h). A $2 \mathrm{~km}$ line transect was conducted at a sea depth of $5 \mathrm{~m}$ and returning at a sea depth of $3 \mathrm{~m}$ during each session.

Snorkel-swim surveys (163 km, 117 h) were conducted by 1 to 2 observers in May and June of 2004 and 2005 at randomly selected sites within the survey area. Sessions lasted an average of $1.7 \mathrm{~h}$ (minimum 1, maximum $3 \mathrm{~h}$ ). A $1 \mathrm{~km}$ line transect was conducted with the observer swimming parallel to shore at a sea depth of $3 \mathrm{~m}$ and returning by wading at a sea depth of $1 \mathrm{~m}$.

On sighting a sea turtle, the GPS location was recorded (using a GARMIN Etrex-legend) while the observer entered the water from the boat/kayak at a distance of at least 5 to $10 \mathrm{~m}$ from the target animal(s) and approached until within underwater visual range (subject to daily variations in underwater visibility, approx. average 4 , minimum 0.5 , maximum $8 \mathrm{~m}$ ), to minimize disturbance of ongoing behaviour. On encountering the animal(s), photographic records were collected in addition to biological, environmental and behavioural observations (including response to underwater observer presence). Photographs were taken using an Olympus Digital 500 (5.0 megapixel) with underwater housing. Video footage, using a Sony DCR-HC32E Handycam with housing, was collected to classify observed behaviours and inter-specific interactions. Sex was estimated using tail length (Casale et al. 2005).

Analyses included only the initial behaviour observed at each sighting event. Non-parametric Chisquare statistics were used for comparative analysis of the behaviour sighting data. We regarded the results to be significant when $\mathrm{p}<0.05$.

\section{RESULTS}

\section{General survey information}

The behaviour of loggerhead sea turtles at initial sighting was recorded at 1534 sighting events of solitary $(n=80$ male, $\mathrm{n}=1335$ female) and social ( $\mathrm{n}=65$ same sex, $\mathrm{n}=54$ mixed sex) activity. This bias towards female turtles partly reflects their location closer to shore where surveys were concentrated. However this ratio may also reflect the highly skewed bias towards females found in hatchling loggerhead turtles in Mediterranean populations (Godley et al. 2001, Mrosovsky et al. 2002).
On average, 1.5 sightings $\mathrm{km}^{-1}$ were made by boat ( $\mathrm{n}=615$ ), 3 sightings $\mathrm{km}^{-1}$ were made by kayak ( $\mathrm{n}=$ 237) and 4 sightings $\mathrm{km}^{-1}$ were made by snorkel-swim surveys. Sightings lasted $2.7 \mathrm{~min}$ on average $(\mathrm{SD}=4$ min, minimum 1, maximum $65 \mathrm{~min}$ ).

We grouped observed behaviour into 4 solitary and 2 social behaviours (Fig. 2) comprising 14 sub-categories (Table 1).

\section{Solitary behaviour descriptions}

Resting. This incorporates both resting on the sea bed and surface-basking (Table 1, Fig. 3A,B, Video clips 1 to 3, see www.int-res.com/articles/suppl/ n002p071_videos/). When resting on the seabed the head, body and flippers were lowered on the substrate. Females never rested within visual range of one another. At 4 sightings large fish (>0.5 m body length) were sighted in close proximity to resting females. At 34 sightings, juvenile saddled bream Oblanda melanura ( 2 to $4 \mathrm{~cm}$ body length) were observed feeding opportunistically on resting turtles that neither solicited nor appeared to respond to this activity. Surface-basking turtles rested at the sea surface or up to $1 \mathrm{~m}$ beneath the sea surface with the head and flippers lowered.

Swimming. This includes along the seabed, in the water column and near the sea surface as well as patrolling by males (Table 1, Fig. 3C,D, Video clips 4 to 6 , see www.int-res.com/articles/suppl/n002p071_ videos/). At 29 sighting events, 6 different fish species

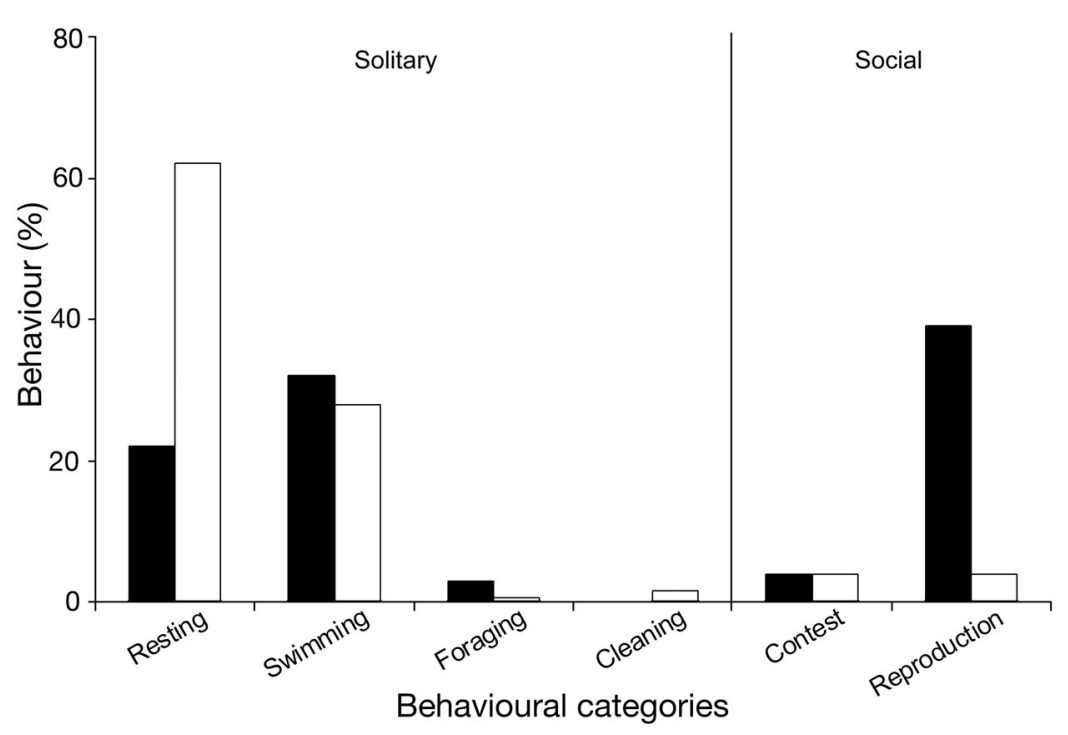

Fig. 2. Caretta caretta. Relative proportions of behaviour exhibited by male (black, $\mathrm{n}=139$ ) and female (white, $\mathrm{n}=1449$ ) loggerhead sea turtles at initial sighting 
Table 1. Caretta caretta. Summary table of the breakdown of loggerhead sea turtle behaviour at each sighting event during surveying

\begin{tabular}{|c|c|c|c|c|}
\hline Status & $\begin{array}{l}\text { Behaviour } \\
\text { category }\end{array}$ & $\begin{array}{l}\text { Behaviour } \\
\text { sub-category }\end{array}$ & Sex & $\begin{array}{c}\text { Number of } \\
\text { sighting events }\end{array}$ \\
\hline \multirow[t]{17}{*}{ Solitary } & \multirow[t]{3}{*}{ Resting } & Resting on seabed & $\begin{array}{l}M \\
F\end{array}$ & $\begin{array}{c}27 \\
676\end{array}$ \\
\hline & & \multirow[t]{2}{*}{ Surface-basking } & $\mathrm{M}$ & 4 \\
\hline & & & $\mathrm{F}$ & 226 \\
\hline & \multirow[t]{8}{*}{ Swimming } & \multirow[t]{2}{*}{ Along seabed } & M & 8 \\
\hline & & & $\mathrm{F}$ & 89 \\
\hline & & \multirow[t]{2}{*}{ In water column } & M & 12 \\
\hline & & & $\mathrm{F}$ & 197 \\
\hline & & \multirow[t]{2}{*}{ Near surface } & M & 21 \\
\hline & & & $\mathrm{F}$ & 121 \\
\hline & & \multirow[t]{2}{*}{ Patrolling } & M & 4 \\
\hline & & & $\mathrm{F}$ & 0 \\
\hline & \multirow[t]{2}{*}{ Foraging } & \multirow[t]{2}{*}{ Infaunal mining } & M & 4 \\
\hline & & & $\mathrm{F}$ & 5 \\
\hline & \multirow[t]{4}{*}{ Cleaning } & \multirow[t]{2}{*}{ Self-cleaning } & M & 0 \\
\hline & & & $\mathrm{F}$ & 6 \\
\hline & & \multirow{2}{*}{$\begin{array}{l}\text { Fish cleaning } \\
\text { symbiosis }\end{array}$} & M & 0 \\
\hline & & & $\mathrm{F}$ & 15 \\
\hline \multirow[t]{5}{*}{ Social } & \multirow[t]{2}{*}{ Contest } & Male-male & $\mathrm{M}+\mathrm{M}$ & 5 \\
\hline & & Female-female & $\mathrm{F}+\mathrm{F}$ & 60 \\
\hline & \multirow[t]{3}{*}{ Reproduction } & Courtship & $\mathrm{M}+\mathrm{F}$ & 34 \\
\hline & & Copulation & $\mathrm{M}+\mathrm{F}$ & 15 \\
\hline & & $\begin{array}{l}\text { Copulation with } \\
\text { interference by } \\
\text { attendant(s) }\end{array}$ & $(\mathrm{M}+\mathrm{F})+\mathrm{M}$ & 5 \\
\hline
\end{tabular}

(adult and juvenile) were recorded swimming in close proximity to turtles (in the folds of the hind flipperbody join, or above or beneath the carapace or head).

Four males patrolling for females were each followed at close proximity by the in-water observer for an average of $43 \mathrm{~min}(\mathrm{SD}=17 \mathrm{~min})$. The males all appeared to swim parallel to shore at sea depths of 0.5 to $3 \mathrm{~m}$. On detecting a female the male swam faster, generally approaching the female side on and nudging/biting at her carapace initiating courtship behaviour. By combining all data sets, we estimated that patrolling males encountered a female every 9 min on average (SD $=3)$.

Foraging. Both males and females were observed mining for bivalves (Table 1, Fig. 3E, Video clips 7 \& 8, see www.int-res.com/articles/suppl/n002p071_videos/). Females made sporadic attempts, but none were observed to be successful. Males foraged close to shore in areas where females also aggregate to rest. Bouts lasted a minimum of $30 \mathrm{~min}$, which was defined as periods when turtles dug in the sand and ended when no digging was reported for $5 \mathrm{~min}$. The males swam along the seabed, and on detecting bivalves in the sand they dug in the sand with their beak using the flippers for momentum. Successful attempts were recognised by the expulsion of segments of crushed mollusc shell from both the nares and oral cavity. By combining all data sets, we estimated that males made digging attempts about twice a minute (mean $38 \mathrm{~s}, \mathrm{SD}=$ 7 ) with a $45 \%$ foraging success rate $(\mathrm{n}=$ 148 attempts).

Cleaning. This includes both selfcleaning and fish cleaning symbiosis (Table 1, Fig. 3F,G, Video clips $9 \&$ 10, see www.int-res.com/articles/suppl/ n002p071_videos/). When self cleaning, turtles repetitively rubbed their heads, flippers and carapace against submerged rocks or anchors. Algae, barnacles and limpets were visibly removed, and distinctive parallel markings were created running the length of the carapace. Based on this uniformity of scratch patterns (different to that created by claw/carapace scratches during mating/ fighting), we were able to detect if this behaviour had been performed recently in all sighted turtles. We found that $55 \%$ of females and $19 \%$ of males sighted had performed this activity at least once during the survey period.

Female turtles were observed visiting a specific cleaning station and actively soliciting cleaning by juvenile sheepshead bream Diplodus puntazzo (12 to $14 \mathrm{~cm}$ body length). The solicitation posture was held until fish approached; the turtle extended her head, with her hind limbs sprawled and the forelimbs stretched forward, and the body slightly raised above the seabed. Turtles were cleaned by an average of 13 fish ( $\mathrm{SD}=4.8)$ at any one time. Bream are omnivorous, and were assumed to be primarily feeding on micro-organisms on the turtles soft and hard body surfaces; however, epidermal skin lesions were also targeted. This caused turtles to react by flicking the head, twisting the body, swimming fast, biting at their own flippers or fish or on rocks, or to depart the cleaning zone altogether. Within an hour of departure 2 turtles returned for repeat cleaning.

\section{Social behaviour descriptions}

Contest. This included female-female and male-male interactions (Table 1, Fig. 3H,I, Video clips 11 to 13, see www.int-res.com/articles/suppl/ n002p071_videos/). Female contests lasted on average $3.4 \mathrm{~min}(\mathrm{SD}=1.02 \mathrm{~min}$ ) and involved ritualized escalation in behaviour from passive threat displays (e.g. head-tail circling) to aggressive combat (e.g. sparring, biting and chasing). The presence of intruder females 
triggered a response in $76 \%$ of observed cases. Contests were usually initiated when the intruder entered the visual range of the resident; however, for $12 \%$ of instances, contests were initiated by tactile advances (nuzzling/biting of carapace) from the intruder. Male contests followed the same pattern of escalation as that of female competition. During fights males would bite, spar, lock flippers while plastron to plastron, attempt to mount, and repeatedly swim to and from each other at speed, until one opponent retreated. In all instances, the retreating male curled its tail under the carapace while the winner held its tail straight.

Reproduction. This includes courtship and copulation with and without male attendants (Table 1, Fig. 3J-L, Video clips 14 to 19, see www.int-res.com/ articles/suppl/n002p071_videos/). Courtship was initiated by a male entering the visual range of a female, advancing quickly and biting at the carapace (Video clip 14). The male would attempt to get behind the female and mount; however, if the female was not receptive, she would counter his actions by attempting to (1) take a vertical position in the water with the plastron facing the male, which sometimes led to the male locking plastrons with the female (Video clips 15 \& 16), (2) maintain head-head position preventing the male from circling around, often trying to obtain a higher horizontal position in the water than the male (Video clip 17), (3) spin out from under a male attempting to mount (Video clip 18), (4) attempt to get behind the male and bite at his tail (Video clip 19). Males attempting to court females during the inter-nesting period were never observed to successfully mount and mate.

Mating was observed on 20 occasions during the pre-nesting period, both on the sea surface and on the seabed. Copulation had already begun when the turtles were initially observed, and males were mounted for periods of at least $40 \mathrm{~min}$ (the total duration was not recorded). Mounted males hooked their fore-flipper claws over the anterior rim of the female carapace and were observed repeatedly biting at the necks of females. Mating appeared to occur more frequently (1) during rough sea conditions when underwater visibility was low (90\%, 18 pairs) and (2) during April (70\%, 14 pairs). Copulation with interference by attendant males was recorded on 5 occasions. Only one attendant was recorded at any one time with mating pairs. One mounted male was successfully dislodged by attendant interference. Attendant behaviour included fast swimming to and from the mating pair and aggressive biting of the mounted male's (and on occasion female's) fore and hind flippers, neck, tail and carapace. During attacks mounted females would attempt to evade the attendant by diving to the seabed and swimming along it, ceasing all movement between attacks.

\section{Female behaviour}

At 1449 female sightings (Fig. 2), significantly more were observed in solitary $(92 \%)$ than social $(8 \%)$ behaviour $\left(\chi_{1}^{2}=1020, p<0.001\right)$. Solitary females were more likely to be found inactive (68\%) than active $(32 \%)\left(\chi_{1}^{2}=164, \mathrm{p}<0.001\right)$. While cleaning behaviour only accounted for $1.5 \%$ of observations, very similar uniform scratch patterns on the carapace (different to that of mating scratches) were documented at over $50 \%$ of female sighting events.

\section{Male behaviour}

At sighting events with male loggerheads present (Fig. 2, $\mathrm{n}=139$ ), analysis of initial behaviour observations indicated that they were just as likely to be found in solitary $(57 \%)$ as social states $\left(43 \% ; \chi_{1}^{2}=2.33, \mathrm{p}=\right.$ $0.1)$. There was no significant difference in the occurrence of active $(61 \%)$ and inactive $(39 \%)$ solitary states $\left(\chi_{1}^{2}=3.24, \mathrm{p}=0.07\right)$. Uniform scratch patterns, identical to that of females observed performing self cleaning, were found on the carapace of males at $19 \%$ sighting events. The proportion of social behaviour observed in males $(43 \%)$ was 5 times greater than that of females $(8 \%)$. Furthermore, the proportion of active solitary behaviour observed in males $(62 \%)$ was double that of females.

\section{DISCUSSION}

Through intensive in-water observations of loggerhead sea turtles during the breeding season, we found that a broad range of behavioural activities were exhibited. Our research differed from existing studies at breeding areas (courtship and internesting) in that, rather than specifically addressing courtship and mating behaviour (Booth \& Peters 1972, Dodd 1988, Frick et al. 2000), or inter-nesting movement patterns (Hopkins-Murphy et al. 2003), we sought to investigate the behavioural ecology of sea turtles during this period.

Our results indicated that in general males were more active and social than females, which probably reflected the need to acquire multiple mates to maximise fitness, whereas female fitness would be maximised by energy conservation to divert resources towards egg development (Hays et al. 2002a, Hopkins-Murphy et al. 2003). However, we observed female loggerheads investing in active behaviours previously unobserved in loggerheads during the breeding period, i.e. that of foraging, cleaning (selfcleaning and fish-cleaning symbiosis) and femalefemale contests. 

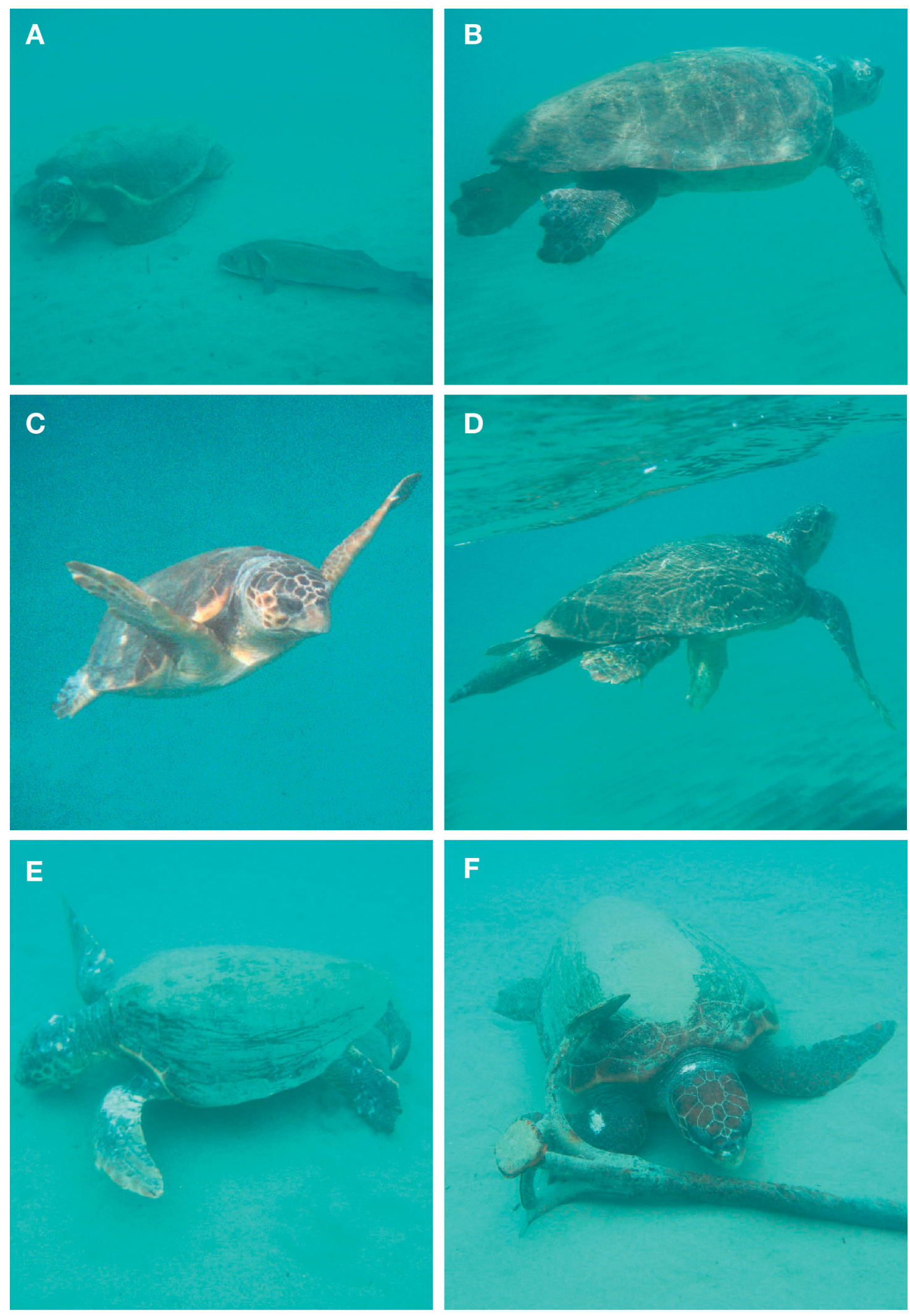

Fig. 3. Caretta caretta. (A) Female loggerhead resting on the seabed; (B) female surface-basking; (C) female swimming; (D) male patrolling for females; (E) male foraging for molluscs; (F) female rubbing against an anchor; $(G)$ female posing at a fish cleaning station manned by sheepshead bream Diplodus puntazzo; $(\mathrm{H})$ antagonistic female interaction; (I) antagonistic male interaction; (J) loggerhead courtship activity; $(\mathrm{K})$ loggerheads copulating; $(\mathrm{L})$ loggerheads copulating with antagonistic attendant male 

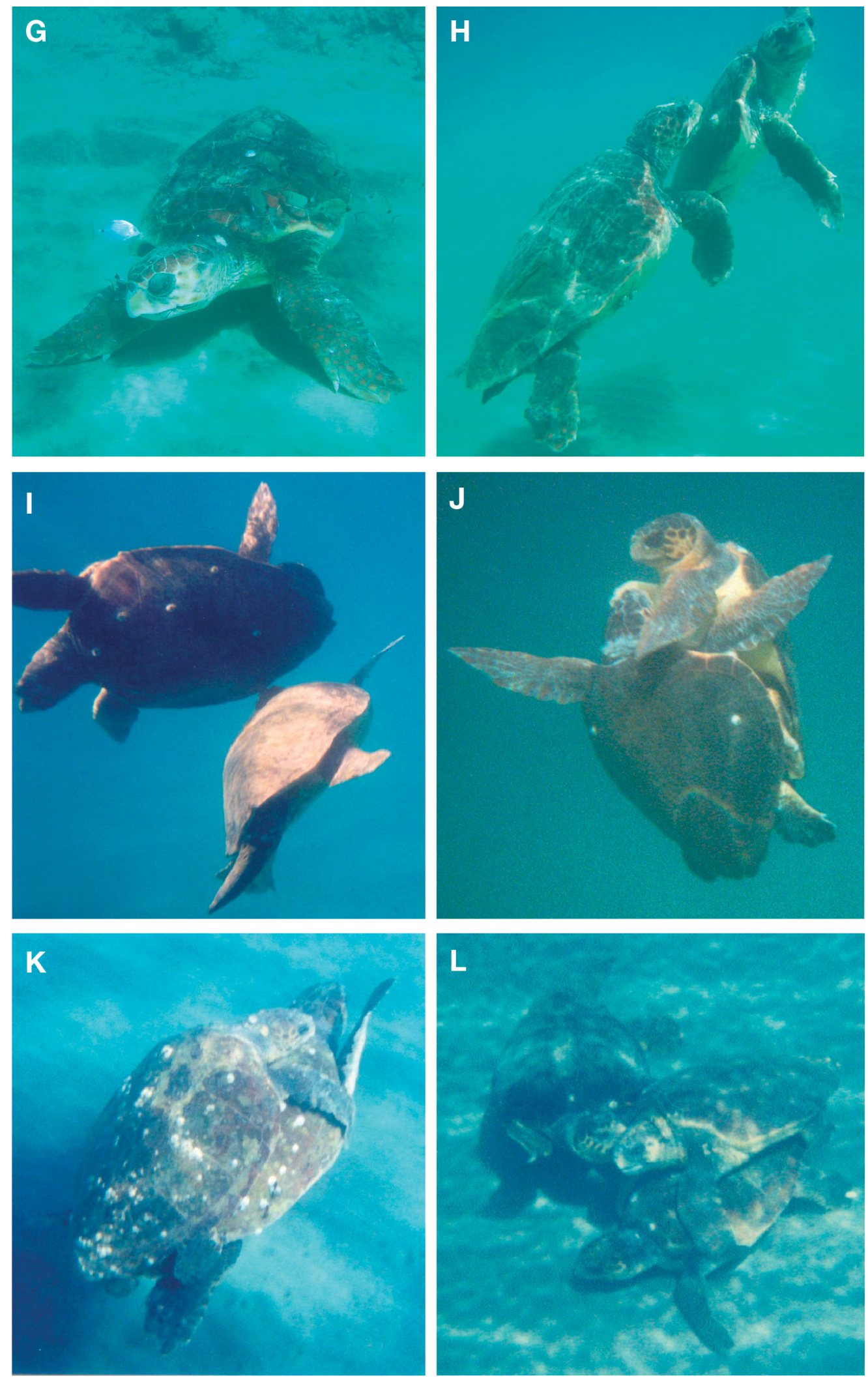

Fig. 3 (continued) 
Contests between individuals over space has received anecdotal mention in sea turtle literature (Limpus \& Limpus 2003), yet our research indicated that antagonistic interactions are a noteworthy component of female loggerhead activity during the breeding period. It is possible that females may be benefiting from (1) thermally optimal sites to enhance egg development, or (2) space to obtain refuge from energy consuming encounters with males patrolling for receptive mates (Booth \& Peters 1972, Whittow \& Balazs 1982, Lee \& Hays 2004).

Both self-cleaning (e.g. green turtles Chelonia mydas: Heithaus et al. 2002) and cleaning symbioses have been recorded in other sea turtle species at foraging and breeding grounds (e.g. green turtles: Losey et al. 1994, hawksbill turtles Eretmochelys imbricata: Sazima et al. 2004). However, high carapace epibiont loads (Frick et al. 1998) and a recent animal-borne sea turtle study (Heithaus et al. 2002) have led researchers to suggest that loggerheads do not invest as heavily in cleaning behaviour as other sea turtle species (Bjorndal 2003). Yet, while we only observed self-cleaning and fish cleaning symbiosis on a few occasions, evidence of self-cleaning behaviour was apparent from the uniform scratch patterns on the carapaces of a large proportion of surveyed male and female turtles, indicating that loggerheads at Laganas Bay do invest in cleaning activity.

Herbivorous foraging behaviour has been documented in one Mediterranean population of female green turtles at a breeding area (Hays et al. 2002b). Similarly, we observed sporadic feeding attempts for molluscs by both female and male loggerheads at Laganas Bay. However, time spent foraging was relatively short, presumably because of the need to spend time and energy on other activities (e.g. males searching for females), and possibly because prey densities were sufficiently low that sometimes it was more profitable (e.g. for females) to simply rest than attempt to feed.

Direct observations of loggerhead sea turtle mating systems in the wild remain rudimentary (Dodd 1988, Frick et al. 2000). Courtship and mating behaviour of loggerheads have been found to follow similar patterns to that documented in other sea turtle species (Booth \& Peters 1972, Rostal et al. 1998). In courtship bouts with unreceptive females we corroborated and expanded on the use of avoidance manoeuvre sequences. Furthermore, we recorded that females would attempt to circle behind persistent males to make offensive advances biting at their tails. As with other species, we observed that males competitively search for receptive females (Jessop et al. 1999) in the form of patrolling but we also documented the presence of male-male combat, possibly for primary mate acquisition. Furthermore, while the presence of antagonistic attendant males in the company of copulating pairs has been recorded in other species of sea turtle (Booth \& Peters 1972), this was not documented in loggerheads (Frick et al. 2000) until the current research.

Direct observations of turtle behaviour are of great value and provide many interesting insights that are difficult, or impossible, to gain from more indirect methods or animal-borne imaging. Studies, comparing direct and indirect methodologies of animal behaviour, have shown that remote-sensing data can distinguish between active and inactive states, however it cannot reliably distinguish the different behaviour patterns within those states (Hansen et al. 1992, Heithaus et al. 2001). Our findings have shown that loggerhead sea turtles exhibit a wider range of behaviour than has previously been documented at breeding areas. It is therefore likely that indirect inferences about movement patterns made from remote-sensing data analysis may be subject to error (as shown by Houghton et al. 2002). It is also possible that jaw activity patterns may be subject to misclassification (Hochscheid et al. 2005) due to the failure to document activities such as sparring and biting in contests and courtship, biting at cleaner fish during cleaning, or biting themselves during self cleaning. The recent development of animal-borne cameras has given researchers of marine vertebrates, such as sea turtles, the opportunity to observe and confirm the underwater behaviour (Davis et al. 1999, Heithaus et al. 2002, Reina et al. 2005, Hays et al. 2006). Hence, knowledge about free-living behaviour, obtained from direct observations, is essential towards improving the accuracy of remote-data interpretation of marine wildlife.

To implement effective wildlife management and conservation plans, accurate information about animal behaviour, habitat use and population dynamics are essential. On Zakynthos, our data may be used to improve the existing national park conservation policies. The protection zones should be amended to take into consideration the function of different habitats with respect to sea turtle activities. Furthermore, sea turtle watching protocols should be refined, limiting in-water watching activities to regions where behaviour is minimally impacted.

In conclusion, direct observational studies in the marine environment are of great value in developing our knowledge of marine vertebrate behaviour, validating remote technologies and contributing towards ecosystem research and environmental monitoring.

Acknowledgements. We especially thank the National Marine Park of Zakynthos for allowing us to conduct this study. We thank the many people who contributed to this research, in particular Martyn Baker, Amanda Banks, Kostas Gounelis, Valia Lianos, Charikleia Minotou, Fanis Nikoloudakis, Charlotte Sahlin and David G. Schofield. 


\section{LITERATURE CITED}

Bjorndal KA (2003) Roles of loggerhead sea turtles in marine ecosystems, Chapter 15. In: Bolton AB, Witherington BE (eds) Loggerhead sea turtles. Smithsonian Institution, Washington, DC, p 235-255

Booth J, Peters JA (1972) Behavioural studies on the green turtle (Chelonia mydas) in the sea. Anim Behav 20: 808-812

Casale P, Freggi D, Basso R, Argano R (2005) Size at male maturity, sexing methods and adult sex ratio in loggerhead turtles (Caretta caretta) from Italian waters investigated through tail measurements. J Herpetol 15:145-148

Davis RW, Fuiman LA, Williams TM, Collier SO, Hagey WP, Kanatous SB, Kohlin S, Horning M (1999) Hunting behaviour of a marine mammal beneath the Antarctic fast ice. Science 283:993-994

Dodd CK (1988) Synopsis of the biological data on the loggerhead sea turtle. US Fish Wildl Serv Biol Rep 88(14):1-110

Frick MG, Williams KL, Robinson M (1998) Epibionts associated with nesting loggerhead sea turtles (Caretta caretta) in Georgia, USA. Herpetol Rev 29:211-214

Frick MG, Slay CK, Quinn CA, Windham-Reid A, Duley PA, Ryder CM, Morse LJ (2000) Aerial observations of courtship behaviour in loggerhead sea turtles (Caretta caretta) from South Eastern Georgia and Northeastern Florida. J Herpetol 34(1):153-158

Godley BJ, Broderick AC, Mrosovsky N (2001) Estimating hatchling sex ratios of loggerhead turtles in Cyprus from incubation durations. Mar Ecol Prog Ser 210:195-201

Hansen MC, Garner GW, Fancy SG (1992) Comparison of 3 methods for evaluating activity of Dall's sheep. J Wildl Manag 56(4):661-668

Hays GC, Broderick AC, Glen F, Godley BJ, Houghton JDR, Metcalfe JD (2002a) Water temperature and internesting intervals for loggerhead (Caretta caretta) and green (Chelonia mydas) sea turtles. J Therm Biol 27:429-432

Hays GC, Glen F, Broderick AC, Godley BJ, Metcalfe JD (2002b) Behavioural plasticity in a large marine herbivore: contrasting patterns of depth utilisation between 2 green turtle (Chelonia mydas) populations. Mar Biol 141: 985-990

Hays GC, Marshall GJ, Seminoff JA (2006) Flipper beat frequency and amplitude changes in diving green turtles, Chelonia mydas. Mar Biol: DOI 10.1007/s00227006-0412-3

Heithaus MR, Marshall GJ, Buhleier BM, Dill LM (2001) Employing Crittercam to study habitat use and behaviour of large sharks. Mar Ecol Prog Ser 209:307-310

Heithaus MR, McLash JJ, Frid A, Dill LM, Marshall GJ (2002) Novel insights into green sea turtle behaviour using animal-borne video cameras. J Mar Biol Assoc UK 82: $1049-1050$

Hochscheid S, Maffucci F, Bentivegna F, Wilson RP (2005) Gulps, wheezes and sniffs: how measurement of beak movement in sea turtles can elucidate their behaviour and ecology. J Exp Mar Biol Ecol 316:45-53

Hooker SK, Baird RW (2001) Diving and ranging behaviour of odontocetes: a methodological review and critique. Mammal Rev 31:81-105

Hopkins-Murphy SR, Owens DW, Murphy TM (2003) Chapter 5: Ecology of immature loggerheads on foraging grounds and adults in internesting habitat in the Eastern United States. In: Bolton AB, Witherington BE (eds) Loggerhead sea turtles. Smithsonian Institution, Washington, DC, p 79-82
Houghton JDR, Broderick AC, Godley BJ, Metcalfe JD, Hays GC (2002) Diving behaviour during the internesting interval for loggerhead turtles (Caretta caretta) nesting in Cyprus. Mar Ecol Prog Ser 227:63-70

Jessop TS, FitzSimmons NN, Limpus CJ, Whittier JM (1999) Interactions between behavior and plasma steroids within the scramble mating system of the promiscuous green turtle, Chelonia mydas. Horm Behav 36(2):86-97

Lee PLM, Hays GC (2004) Polyandry in a marine turtle: Females make the best of a bad job. Proc Natl Acad Sci 101(17):6530-6535

Limpus CJ, Limpus DJ (2003) Biology of the loggerhead turtle in western South Pacific Ocean foraging areas, Chapter 6. In: Bolton $\mathrm{AB}$, Witherington $\mathrm{BE}$ (eds) Loggerhead sea turtles. Smithsonian Institution, Washington, DC, p 199-210

Losey GS, Balazs GH, Privitera LA (1994) Cleaning symbiosis between the wrasse, Thalassoma duperry, and the green turtle, Chelonia mydas. Copeia 3:684-690

Margaritoulis D (2005) Nesting activity and reproductive output of loggerhead sea turtles, Caretta caretta, over 19 seasons (1984-2002) at Laganas Bay, Zakynthos, Greece: The largest rookery in the Mediterranean. Chel Cons Biol 4(4): 916-929

Margaritoulis D, Argano R, Baran I, Bentivegna F and 11 others (2003) Loggerhead turtles in the Mediterranean: present knowledge and conservation perspectives. In: Bolton AB, Witherington BE (eds) Loggerhead sea turtles. Smithsonian Institution, Washington, DC, p 175-198

Meadows D (2004) Behaviour of green sea turtles in the presence and absence of recreational snorkellers. Mar Turtle Newsl 103:1-4

Miller JD, Limpus CJ, Godfrey MH (2003) Nest site selection, oviposition, eggs, development, hatching, and emergence of loggerhead turtles. In: Bolton AB, Witherington BE (eds) Loggerhead sea turtles. Smithsonian Institution, Washington, DC, p 125-143

Mills DJ, Verdouw G, Frusher SD (2005) Remote multi-camera system for in situ observations of behaviour and predator/prey interactions of marine benthic macrofauna. NZ J Mar Freshw Res 39:347-352

Mrosovsky N, Kamel S, Rees AF, Margaritoulis D (2002) Pivotal temperature for loggerhead turtles (Caretta caretta) from Kyparissia Bay, Greece. Can J Zool 80: $2118-2124$

Myers AE, Lovell P, Hays GC (2006) Tools for studying animal behaviour: validation of dive profiles relayed via the Argos satellite system. Anim Behav 71:989-993

Piraino S, Fanelli G, Boero F (2002) Variability of species' roles in marine communities: change of paradigms for conservation priorities. Mar Biol 140:1067-1074

Reina RD, Abernathy KJ, Marshall GJ, Spotila JR (2005) Respiratory frequency, dive behaviour and social interactions of leatherback turtles Dermochelys coriacea during the inter-nesting interval. J Exp Mar Biol Ecol 316:1-16

Rostal DC, Owens DW, Grumbles JS, MacKenzie DS, Amoss MS Jr (1998) Seasonal reproductive cycle of the Kemp's Ridley sea turtle (Lepidochelys kempi) Gen Comp Endocrinol 109:232-243

Sazima IA, Grossman A, Sazima C (2004) Hawksbill turtles visit moustached barbers: cleaning symbiosis between Eretmochelys imbricata and the shrimp Stenopus hispidus. Biota Neotropica 4:1-6

Whittow GC, Balazs GH (1982) Basking behavior of the Hawaiian green turtle (Chelonia mydas). Pac Sci 36:129-139

Wood JR, Wood FE (1980) Reproductive biology of captive green sea turtles (Chelonia mydas). Am Zool 20:499-505

Submitted: June 17, 2006; Accepted: October 5, 2006

Proofs received from author(s): November 24, 2006 